Мина М. Ђурић

mina.m.djuric@gmail.com

Филолошки факултет

Универзитет у Београду
УДК 378.147::821.163.41

82.03:821.163.41

https://doi.org/10.18485/mks_knsjkk_polozaj.2020.ch3

\title{
ПРЕВОДИЛАЧКЕ НАПОМЕНЕ ЗА ДЕЛА СРПСКЕ КЊИЖЕВНОСТИ У УНИВЕРЗИТЕТСКОЈ НАСТАВИ
}

У раду се анализирају улога и значај преводилачких напомена одређених текстова српске књижевности као својеврсних посредника међу различитим језицима и културама. Додатне напомене преводилаца књижевноуметничких дела тумаче се као важан чинилац за мотивацију читања и подстицање продубљеније рецепције српске литературе у оквирима друге академске средине и шире читалачке публике.

Кључне речи: српска књижевност, српска књижевност 20. века, превод, преводилачке напомене, универзитетска настава. ${ }^{1}$

Деценија бројних годишњица (међу којима се издвајају и обележавања округлих датума, нпр.: двеста година од објављивања првих Вукових дела, сто педесет година од Вукове смрти, двеста година од штампања првог издања Српског рјечника; сто двадесет пет година од рођења Момчила Настасијевића; осамдесет година од рођења Данила Киша, тридесет година од Кишове смрти и многи други), изузетан је подстицај да се успоставе прилике за поновна промишљања поводом дела, превода и иностране рецепције изабраних аутора, и то кроз анализе различитих облика наставих и ваннаставних, књижевних и културних активности, како у земљи, тако и у свету. У том контексту чини се да би проучавања српске и других словенских књижевности на домаћим и иностраним универзитетима, као и у школама, према литерарним вредностима и оригиналним одговорима пи-

1 Текст је настао као резултат рада на пројекту Института за књижевност и уметност, Београд, Смена поетичких парадигми у српској кюижевности двадесетог века: национални и европски контекст (178016), који финансира Министарство просвете, науке и технолошког развоја Републике Србије. 
саца на многобројне поетичке изазове 19, 20. и 21. века, требало да буду још чешће понуђена у компаративним контекстима изучавања светске „књижевности као система, као цјелине” (Делић 2008: 451). Несумњиво је да би нарочиту врсту подстицаја за то омогућиле и интерпретације превода књижевних дела као вид сагледавања важног аспекта контекстуализације текстова у другој културној и научној средини. ${ }^{2}$ Уз чврсто заснована књижевноисторијска и књижевнотеоријска полазишта, као и разматрања основа стваралачке рецепције, настава посвећена традуктолошким тумачењима светскости српске и других словенских књижевности могла би да обезбеди мотивишуће претпоставке за вишесмерно „боље разумијевање и освјетљавање” (Делић 2008: 452) различитих културних образаца (уп. Benedikt 1976), нарочито ако се има у виду медијаторска улога преводилаца (уп. Đurišin 1992: 31-39), а на истакнутом месту њихових додатних напомена у оквиру превода.

Стога би у токовима универзитетске наставе српске књижевности у земљи и иностранству било изузетно драгоцено и вредно да се уз упоредно помно читање и тумачење оригинала и превода српске књижевности, интерпретативна пажња усмери и ка преводилачким напоменама у тексту. На тај начин би се, са једне стране, стекла продубљенија академска знања о врсним преводиоцима српске књижевности и њиховим стваралачким поступањима, као и о поетички и традуктолошки изазовним изборима, како литерарно, тако и културолошки утемељеним одлукама. Са друге стране, проучавањем позиције преводиоца као приређивача одређених напомена нагласио би се својеврсни интерпретативни „вишак” и значајан добитаку полилогу књижевних традиција, проистекао из перспективе односа полазне и циљне културе превода и многоструко динамизованих променакада се имају у виду време, средина и друге друштвено-историјске околности.

У компаративним увидима како у односу на време објављивања превода, тако и на језичку средину у којој се објављује, мо-

2 Поводом увиђања значаја превода текстова српске науке о књижевности у другој половини 20. века за овакву врсту контекстуализације в. Ђурић 2018: 85-98. 
тивишуће за тумачење могу да буду и разноврсне преводилачке напомене у вези са преводом имена у делима. Тако у историјама транслатологије вишезначних именовања остају забележене интригантне дискусије поводом (не)могућности превода имена из наслова драме Оскара Вајлда The Importance of Being Earnest (Wilde 2011), које се разрешавају или у смеру да се име у преводу остави непромењеним и тиме, можда, у циљном језику учини ризичним статус полисемије из оригинала или пак да се прво пренесе значење имена у преводу, а онда да се стваралачки приступи обликовању имена у циљном језику (Nemark 1988: 215; Lobato, Brisolara 2015: 34). У анализи Вајлдовог превода који је објављен у Бразилу - A importância de ser prudente (Wilde 2014; Lobato, Brisolara 2015: 29-37), и поред запажања да у преведеном тексту, услед одабира другог смера поступања, Prudente бива „једино име које није енглеско" (Lobato, Brisolara 2015: 34), у неком смислу се превод наслова ипак оценио као промишљена одлука, посебно пошто се сагледала традиција превођења Оскара Вајлда у оквирима циљне културе (Lobato, Brisolara 2015: 33). Један од врло посвећених аутора изазовима превођења свог дела био је и Владан Десница, о чему сведочи, између осталог, и његова преписка богата дискусијама у вези са преводима текстова на италијански језик (Ђурић 2009: 399-423). Колико су преводиоци Десничиног романа Прољећа Ивана Галеба запажали сложеност у преводу имена главног јунака, односно проблематичност питања да ли се вишеслојни склопови значења конотирани тим именом актуализују и у његовим преносима у наслову на друге језике, сведоче и преводиоци који су се, (не)свесно подстакнути и Десничиним поступком одабира Игре прољећа и смрти за поднаслов романа (Десница 2008), одлучили да као наслове у преводима варивају управо поднасловна одређења, и то, нпр., у преводу на пољски - Niespokojne wiosny (Desnica 1960), на мађарски - A tavasz és a halál játékai (Desnica 1962), на словачки језик - Vlnenie jarí a umierania (Desnica 1967).

Уколико се пак имена не налазе у насловима, а преводиоци осећају да би на језику превода за њихово потпуније разумевање били неопходни коментари, онда их често обликују у виду фус- 
ноте или додатне напомене на крају издања, а неретко придодају управо уз преводе народне књижевности. Према превођеним примерима из народне књижевности, увиђа се да је углавном потребно оставити напомену о етимолошком значењу одређених имена кључних за разумевање песме или проблема који се у делу актуализује. Тако, на пример, Џон Бауринг у преводу српске народне поезије на енглески језик, а међу преводилачким изборима и песме „Зидање Скадра”, уз стихове: „'Не мучи се, Вукашине краље, | Не мучи се и не харчи блага; | Не мо'ш, краље, темељ подигнути, | А камоли саградити града, | Док не нађеш два слична имена, | Док не нађеш Стоју и Стојана, | А обоје брата и сестрицу, | Да зазиђеш кули у темеља [...]" (Вук, СНП II, бр. 26; подвлачење М. Ђ.), односно уз њихов превод: „[...] 'Thou King Vukashin! vain thine efforts! - I Vain thine efforts - all thy treasures wasting! | Never, never wilt thou build the fortress, I If thou find not two same-titled beings, | If thou find not Stojan and Stojana: | And these two - these two young twins so loving; | They must be immured in the foundation [...]" (Karadžić 1827: 64; подвлачење М. Ђ.), додаје и следећу напомену, која се односи на имена из стиха „Док не нађеш Стоју и Стојана” (Вук, СНП II, бр. 26; подвлачење М. Ђ.): „These are both Serbian names, and the point of the ballad must be seen in their affinity to the verb stojiti, to stand, stojnitza, standing (statio)" (Бауринг у Karadžić 1827: 64). Иако имена не преноси сасвим прецизно - не препознаје их у основном облику као Стоја и Стојан, већ као Стојан и Стојана, мењајући им и редослед, вероватно ради чувања версификационе структуре стиха (уп. Вук, СНП II, бр. 26; Karadžić 1827: 64), Бауринг у напомени, кроз варијацију облика за који су имена етимолошки везана, јасно указује на значај ове релације као незаобилазног упоришта у тумачењу песме. Потреба да се у преводу појасни одабир баш ових имена у песми „Зидање Скадра” истакла сеи у њеном преводу на немачки језик, који је начинила Тереза Албертина Лујза фон Јакоб Робинсон, а који је, имајући у виду, између осталог, и форму и распоред имена из наведеног стиха, вероватно утицао ина друге преводе: „'König Wukaschin, du quälst umsonst dich! | Quälst umsonst dich, all' dein Gut verschwendst du! | Nicht den Grund vermagst du zuerheben, | Wie willst du die Feste 
selber bauen! | Findest du nicht zwei gleichnam'ge Wesen, | Findest du nicht Stojan und Stojana, | Und die Beiden, leibliche Geschwister, | Sie im Fundamente zu vermauern [...]" (Karadžić 1853: 78-79; подвлачење М. Ђ.). Уз превод стиха „Док не нађеш Стоју и Стојана” (Вук, СНП II, бр. 26), Талфи дописује и напомену у којој ова имена везује за њихово етимолошко порекло, узимајући у обзир да говорнику немачког културног подручја то највероватније није познато, а веома је индикативно за тумачење песме: „Stojiti, mit welchem Worte jene Namen zusammenhängen, heißt: stehen, bestehen, dauern. Nur durch diese Erklärung erhält die Bedingung der Willa einigen Sinn" (Талфиј у Karadžić 1853: 79). Осим распореда имена и њихових облика који су, као и у претходно поменутим, заступљени и у француском преводу песме „Зидање Скадра”, који је начинила Елиз Војар:,'Roi Wukaschin! en vain tu te tourmentes; | En vain tu prodigues ici tous tes trésors; | Tu ne peux seulement asseoir les fondements. | Comment veux-tu bâtir la forteresse, | Si tu ne trouves pas deux êtres d'un pareil nom, | Si tu ne trouves Stojan et Stojana? | Sache trouver les deux frères germains | Pour les faire murer dans les fondations [...]" (Karadžić 1834: 206), и овде се додаје преводилачка напомена уз стих „Док не нађеш Стоју и Стојана” (Вук, СНП II, бр. 26), која гласи: „Le mot qui répond à celui de stojiti est demeurer, subsister, durer. Cette explication donne seule quelque sens aux paroles de la Wila” (Bojap y Karadžić 1834: 298). Примеђује се да и овај тип преводилачке напомене, имајући као узор Талфијин предложак из првог издања 1825. године (уп. Талфи у Karadžić 1825), не само што објашњава значење конкретних имена као непознатих речиу песми већ на микро и макроплану имплицитно усмерава и даље тумачење Вилиних речи упућених краљу Вукашину. Дакле, поређењем ових примера преводилачких напомена уз стих „Док не нађеш Стоју и Стојана” (Вук, СНП II,

${ }^{3}$ Изражена улога преводилачке напомене у иницирању анализе дела или истицању потенцијалног упоришта тумачења може да се запази и у напомени приређивача уз руски превод „Хасанагинице” који је начинила Ана Ахматова: „А дитяте малому послала одеяльце - кольбель закутать - Свободный перевод. В оригинале: 'А малому у бешици синку, | Њему шаље убошке хаљине', т. е. нищее платье. Смысл этого подарка неясен. Может быть, Хасанагиница хотела показать, что ребенок без нее - бедный сирота?” (Голенишчев-Кутузов у Караджич 1963: 183, 339). 
бр. 26) из песме „Зидање Скадра” на немачком, енглеском и француском језику може да се закључи да су управо напомене преводилаца те које ојачавају потребу паралелног читања оригинала и превода, да успостављају непремостиве везе ка ширем културолошком контексту оригинала, да на одређеним упоришним местима задржавају елементе оригинала и тиме читаоца усмеравају ка продубљенијем упознавању језика и уочавању значаја мултилингвалног контекста, као и да представљају иницијално место тумачења песме у другој академској, наставној, научној или широј читалачкој средини.

Изузетна важност оваквих преводилачких напомена могла би да се проматра кроз историју српске књижевности и њених превода, а када се имају у виду претходни примери, нарочито у праћењу комплекса мотива који се везују за питања савладавања препрека у подизању грађевина. ${ }^{4}$ У том контексту подстицајно би било и у односу на претходни пример да се анализира варијација овог мотива у првој глави Андрићевог романа На Дрини ћуприја:

„Знали су да је градњу ометала вила бродарица, као што је одувек и свуда понеко ометао сваку градњу, и ноћу је рушила оно што је дању саграђено. Док није 'нешто' проговорило из воде и саветовало Раду Неимару да нађе двоје нејаке деце, близнади, брата и сестру, Стоју и Остоју по имену, и да их узида у средње стубове моста" (Андрић 1965: 12; подвлачење М. Ђ.).

Без обзира на то да ли ће преводиоци Андрићевог романа на друге језике узимати у обзир у транслатолошкој традицији присутне преводилачке напомене које се везују за овај мотив, да ли ће додавати нове напомене и белешке или не, у сваком случају се примећује да је уз конкретне традуктолошке одлуке овај пример и у оригиналу, и у преводима врло индикативан за анализирање поетичког дијалога између модерности и традиције, ${ }^{5}$ и то посебно начина на који је усмена баштина стваралачки реципирана у двадесетовековној књижевности. Иако у енглеском преводу Ло-

4 За компаративну анализу овог мотива в. нпр.: Сувајџић 2011: 61-73.

5 Поводом начина тумачења односа традиције и модерности в. Ђурић 2013: $115-125$. 
вета Едвардса на почетку романа На Дрини ћуприја постоји и белешка о изговору имена (Edwards 2016: 19-20), а у тексту се неки појмови који се задржавају на језику изворника остављају курзивом, нпр.: „kapia” (Andrić 2016: 23), „sofa”, „tarih” (Andrić 2016: 24), „salep” (Andrić 2016: 30), „kolo”, , vilas” (Andrić 2016: 31), „,halva” (Andrić 2016: 100), у конкретном сегменту превода за имена Стоје и Остојене налазе сепосебне напомене:

„They knew that the vila of the boatmen had hindered its building, as always and everywhere there is someone to hinder building, destroying by night what had been built by day, until 'something' had whispered from the waters and counselled Rade the Mason to find two infant children, twins, brother and sister, named Stoja and Ostoja, and wall them into the central pier of the bridge" (Andrić 2016: 25; подвлачење, осим vila, М. Ђ.).

Иако се у немачком преводу Андрићевог романа на крају књиге додају објашњења страних речи и израза који су се на немачки пренели (Jonas, Wolf-Grießhaber 2018: 482-484), одлука у вези са статусом имена Стоје и Остоје у немачком преводу одломка из прве главе Андрићевог романа На Дрини ћуприја врло је сродна примеру из енглеског превода:

„Sie wissen, dass die Wassernixe, die Vila, den Bau gestört hat, so wie schon immer und überall irgendwer einen Bau stört, und nachts abgerissen hat, was am Tag aufgebaut worden war. So lange, bis ein 'Etwas' aus dem Wasser zu sprechen begann und dem Baumeister Rade riet, zwei kleine Kinder, Zwillinge, Bruder und Schwester, namens Stoja und Ostoja zu suchen und in den Mittelpfeiler der Brücke einzumauern" (Andrić 2018: 11; подвлачење M. Ђ.).

У том смислу би управо на овим местима анализе Андрићевог романа и његових превода, у универзитетску наставу било добро да се укључи и вертикала проматраног мотива из књижевности која се преводи, да се контекстуализује у оквирима сродних мотива из светске књижевности, као и да се одабрани одломци и целине дела компаративно тумаче у контексту преводилачких 
напомена неких од ранијих књижевних остварења са сродним мотивом, преведених на циљни језик. На тај начин би се, са једне стране, успоставила својеврсна историјска поетика превода дела одређеног језичког подручја, а, са друге стране, кроз преводилачка деловања скренула би се пажња и на поетички изазовна места за тумачења текста, која се наглашавају и откривају у преводима.

Колико је вредно да се постојаност полисемије одређене речи, нарочито када она може да упућује и на име, нагласи и преводилачком напоменом, показују пример песме „Зора” Момчила Настасијевића и превод на немачки језик који је начинио Роберт Ходел (Nastasijević 2013: 88-89).Већ уз наслов Настасијевићеве песме „Зора” на немачком језику - „Morgenröte” (Nastasijević 2013: 89), Ходел додаје напомену да поред значења речи које се односи на рано јутро (уп. РСАНУ), наслов песме на језику оригинала може да се повеже и са значењем којим се указује на женско име: „Der Originaltitel 'Zora' ist auchein Frauenname. Dassel begilt für das Gedicht 'Dafina', dessen Titel 'Ölweide' bedeutet [...]" (Ходел у Nastasijević 2013: 89; подвлачење М. Ђ.). ${ }^{6}$ Овом преводилачком напоменом имплицитно се указује и на семантичку слојевитост песме, која се сугерише већ другим стихом: „Хеј, на белом коњу | зори ми зора и девојка" (Настасијевић 1991: 15; подвлачење M. Ђ.), односно у преводу на немачки: „Hei, aufeinem Schimmel | leuchten mir Morgenlichtund Mädchen" (Nastasijević 2012: 89; подвлачење М. Ђ.). Преводилачка напомена Роберта Ходела којом се скреће пажња на вредност наслова значајна је не само због диференцираних могућности тумачења песме већ и због чињенице да се наслов „Зора” појавио тек у коначном облику Настасијевићеве песме, којој је претходило тринаест верзија са варираним насловима, и то „Песма пролећа” (прва, друга верзија), „Песма у пролеће” (трећа, пета верзија), „Поздрав у пролеће” (четврта верзија), „Песма с пролећа” (шеста верзија), „Јутарња песма” (седма, осма верзија), „Трешње” (десета верзија), „Девојци” (једанаеста верзија), „Песма на уранку” (дванаеста верзија), „Чобан” (тринаеста верзија) и без наслова (девета верзија) (уп. Настасијевић 1991: 156-167; Петковић 1991: 624-626). Управо се преводилач-

${ }^{6}$ О хомографима код Настасијевића в. и Hodel2014: 78-79. 
ком напоменом важност стваралачког трагања за одговарајућим насловом посредује и у преводу, а њоме се имплицитно и усмерава читалац на поетички незаобилазне инстанце Настасијевићевог рада и тумачења Настасијевићевог дела у универзитетској настави у земљи и иностранству - на поређење варијаната (уп. и Петковић 1995).

Двосмерност тумачења Настасијевићевих наслова, којима се подразумева и женско име, Роберт Ходел у истој преводилачкој напомени даје и за песму „Дафина”: „Der Originaltitel 'Zora' ist auch ein Frauenname. Dassel begilt für das Gedicht 'Dafina', dessen Titel 'Ölweide' bedeutet [...]" (Ходел у Nastasijević 2013: 89; подвлачење М. Ђ.). Таква напомена је изразито важна када се имају у виду вишеструкости и динамика могућих алтернација значења доминантног мотива из насловау односу на прву и трећу строфу Настасијевићеве песме „Дафина”: „Кад нељубљено мре, | тмоло је ваздухом | на страст. || [...] Дафину на гроб не сади, | тмоли је дах из ње, | сабласно мами у таму" (Настасијевић 1991: 19; подвлачење М. Ђ.). То се у преводу уочава у различитом одабиру речи - у наслову je „Dafina”, што сугерише да је у питању женско име, а у трећој строфи је „Ölweide”, што показује да је у питањуодабир речи којим се означава биљка: „Wenn Ungeliebtes stirbt, | ist stickig die Luft | nach Leidenschaft. || [...] Setz die Ölweide nicht aufs Grab, | stickig aus ihr der Atem, | lockt gespenstischin die Finsternis" (Nastasijević 2013: 97; подвачења М. Ђ.). ${ }^{7}$ У ствари, захваљујући преводилачкој напомени о полисемији наслова на језику оригинала (уп. РСАНУ), и у циљном тексту је сачувана сложеност значења коју песма подразумева. Уз то, када се из перспективе ове преводилачке напомене и улоге наслова у њој, посебно у односу на исту реч која се у коначном облику употребљава у трећој строфи песме „Дафина” (Настасијевић 1991: 19), сагледа претходних седам верзија ове Настасијевићеве песме, увиђа се да је један део својих избора - наслов „Дафина” и стих „Дафину на гроб не сади”, уз промене интерпункције кроз верзије, Настасијевић имао већ у

7 У вези са тим уп. и следећи закључак Роберта Ходела: „I kod nekih identičnih leksema princip polisemije ponekad vodi osamostaljivanju pojedinih sema, tako da je $\mathrm{u}$ prevodu bolje upotrebiti različite reči” (Hodel 2014: 74). 
другој верзији песме, поновио у трећој, четвртој и петој верзији (Настасијевић 1991: 185-187), у шестој задржао идентичан стих, али песму исписао без наслова (Настасијевић 1991: 187), док је у седмој верзији вратио наслов и оставио исти стих (Настасијевић 1991: 189; уп. и Петковић 1991: 628-629). Испитивање верзија показује да када Настасијевић дође до решења у песми којим је задовољан, без обзира на то да ли је у питању нека ранија верзија или је то производ дуготрајнијег процеса стваралачког рада, најчешће је са минималним променама задржава до коначног облика песме (уп. Петковић 1995). Дакле, управо би на поетички дубоко укорењен начин тумачења Настасијевићевих стваралачких избора могла да подстакне анализа превода, а нарочито преводилачких напомена у тексту, што би умногоме утицало на још свестраније приступе настави књижевности и језика на универзитетском нивоу и у земљи, и у иностранству.

Уз немачки превод песме „Ђурђевци” Момчила Настасијевића - „Maiglöckchen” (Nastasijević 2013: 91), Роберт Ходел оставља опширнију напомену у којој се назив цвета на језику оригинала повезује са именом свеца Георгијаи уз то даје опис народних обичаја за Ђурђевдан, међу којима је и плетење венаца од ђурђевака:

„Der Originaltitel 'Đurđevci' ist vom Namen Đurđe (Georg) abgeleitet. Am 6. Juni, dem Tag des Heiligen Georg, wird der Wechsel vom Winter in den Sommer gefeiert. Mit diesen Feiern ist auch mancher vorchristliche Brauch verbunden, zum Beispiel das rituelle Baden im Fluss mit reinigenden Pflanzen, das Flechten von Maiglöckchenkränzen oder das Umgürten mit Weiden zum Zeichen der Fruchtbarkeit und des Wachstums" (Ходел у Nastasijević 2013: 91; подвлачење М. Ђ.).

Овај додатак преводиоца доприноси продубљенијем повезивању иностраних реципијената са култом празничне атмосфере, познате матерњим читаоцима оригинала и према сачуваним обичајима, и према њиховој актуализацији у различитим књижевним делима (нпр. у приповеци „Ђуђевдан” Боре Станковића (Станковић 1899: 1) или у роману Дервиш и смрт Меше Селимовића (Селимовић 2008: 35) и др.). Управо је таква атмосфера 
евоцирана као подразумевајући контекст, или његово изневерено очекивање (уп. и Hodel 2014: 67), у стиховима Настасијевићеве песме „Ђурђевци”: „Сета ме у чедни дан, | кад улицама продају Ђурђевке. || Не враголи ми, | не смеј се, враголанко. | То у родини она | болује сету без лека. || Занаго росне у јутра | црвеном врвцом везивала" (Настасијевић 1991: 16; подвлачење М. Ђ.), што је преведено као: „Wehmut mich am lauteren Tag, | wenn in den Straßen Maiglöckchen zu kaufen. || Treibkeinen Ulk mit mir, | lach nicht, Schalk. | In der Heimat eine, | an Wehmut ohne Heilung krankt. || Vergeblich tauige am Morgen | mit rotem Band sie schnürte" (Nastasijević 2013: 91; подвлачење М. Ђ.). Како су кроз верзије - већ од прве, па до шесте - прва два стиха, осим према интерпункцији и одабиру великог или малог слова на почетку другог стиха, идентични онима из коначног облика песме - „Сета ме у чедни дан, | кад улицама продају ђурђевке" (Настасијевић 1991: 16; уп. Настасијевић 1991: 168-172; Петковић 1991: 626), запажа се да је већ од Настасијевићеве треће верзије уместо наслова „Сетна песма” као насловни симбол превладала кључна реч из другог стиха - „Бурђевци” (Настасијевић 1991: 168-172). Значај Ходелове напомене о празничној атмосфери и народним обичајима Ђурђевдана за ову песму (уп. и Hodel 2014: 67) издваја се и у контексту поређења са преводилачким напоменама у другим делима у којима се јавља сродан појам. И у Настасијевићевој песми „Ђурђевци” (Настасијевић 1991: 16), као и у одредници „Ђурђевдан”, која се разликује у првом и другом издању Вуковог Српског рјечника, ипак доминира контекстуализација народних обичаја који се везују за поменути празник (Вук, Рјечник I: 161-162; Вук, Рјечник II: 226). Уз превод на немачки језик одреднице „Ђурђевдан” из другог издања Cpnског рјечника (Вук, Рјечник II: 226), преводилац Анете Ђуровић одлучила је да укључи и напомену којом се наглашава да је у питању и дан празновања свеца заштитника, односно да је то честа српска слава: „Der Đurđevdan ist eines der am weitesten verbreiteten Schutzpatronenfeste (slava) der Serben” (Ђуровић у Karadžić 2015: 65). Преводилачком напоменом уз одредницу из Српског рјечника или пак преводилачком напоменом уз Настасијевићеву песму „Ђурђевци” нагласило се посредовање културолошке сфере која 
је изразито подстицајна као упориште за потпунију интерпретацију синкретичности сакралних и профаних обреда која се везује за празник описан у Српском рјечнику или пак на којој је заснована херметичка сложеност Настасијевићеве песме.

Колико одређена имена могу да имају знаковиту интертекстуалну вредност у односу на културну традицију у оквиру које је аутор стварао, показује и преводилачка напомена Марка Томпсона уз један од ранијих текстова Данила Киша (Thompson 2013: 109-111). У Кишовом тексту „Нојев ковчег (Из бележнице г. Мака)”, насталом 1959. године, који је бави феноменом двојника, јавља се узгредно поређење двојничке силине са моћима Баш-Челика:

„Spokoj se rađa u komplikovanom no $\mathrm{u}$ isto vreme prostom mehanizmu srca; u jednoj od tih četvorina što se nazivaju komorama i pretkomorama nalazi se zaključan Wertheim-bravom taj silni kaobaščelik Dvojnik, koji kad ostane nasamo s tobom izlazi, onako golem, uprkos svim bravama i alarmnim uređajima" (Kiš 2007: 45; подвлачење М. Ђ.).

Овај одломак у Томпсоновом преводу на енглески језик садржи дужу преводилачку напомену, у којој Томпсон представља народну бајку „Баш-Челик” (Вук, СНП, Додатак, бр. 1) не би ли иностраној публици приближио значење како Кишовог поpeђења - „taj silni kao baščelik Dvojnik” (Kiš 2007: 45), тако и, очигледно, вишеструко инспиративног мотива из народне традиције:

„This simile ('silni kao bašcelik') alludes to one of the bestknow villains in Serbian folklore, the mighty Baš Celik ('great steel' or 'big steel'). The story goes like this. An old king has three sons and three daughters. Before he dies, he tells his sons to give his daughters to the first comers. The youngest prince insists on respecting their father's wish, and the girls are taken away by ominous suitors. After the brothers hear nothing from their sisters, they set out in search of them. They survive adventures withdragons, serpents, and man-eating giants. The youngest prince saves a princess, whom he marries. Before he goes travelling one day, the king (his father-in-law)entrusts nine keys to this prince. The first eight chambers hold treasure, he says, and then warns him not to enter the ninth on any account. The prince of 
course disobeys, and in the ninth chamber he finds Baš Celik, in steel chains up to his knees, both arms manacled to the elbows, unable to move an inch. 'Bring me a drink of water from the pump', Baš Celik pleads, 'and I will grant you an extra life.' The prince fills a pitcher (encrusted with gems) and gives it to Baš Celik. 'Give me another drink and I shall grant you another life', he says. Again the prince complies. Baš Celik promises the prince a third life if he will just sprinkle water on his head. But this liberates Baš Celik, who bounds awaylike lightning, seizes the princess, spreads his wings and flies off. The king urges the prince not to follow: it would mean certain death; he will find him another wife instead. Again the prince disobeys and sets out to rescue his princess. On the way he meets the Dragon King who warns him to go no further: even with his army of 7000 dragons, he himself could not defeat Baš Celik. The Falcon King and the Eagle King tell him the same. The valiant prince will not be dissuaded. He finds and fights Baš Celik, who quickly rids him of his spare lives. 'Go home now and don't lose the life God gave you', he thunders. The three animal kings rush to his support with their armies, but in vain. Resolved to try cunning instead of force, they discover that the villain's courage is hidden in a bird inside the heart of a fox on a distant mountain. When they catch the bird and kill it, Baš Celik dies. The prince takes back his wife and home they go. - This minuscule allusion to folklore is one of very few in Kiš's work. It opens like a loophole on to a hinterland of pre-modern archetypes" (Thompson 2013: 110).

То што је у преводу овог текста Данила Киша у једној од фуснота чак двадесетак редова усредсређено на предочење народне бајке „Баш-Челик” (Вук, СНП, Додатак, бр. 1) засигурно сведочи и о квалитету бајке, о комплексности њеног насловног мотива, али и о вредности представљања интертекстуалне везе (уп. Hodel 2014: 69). Колико се структура ове бајке уклапа у интернационалне оквире, показује и један Томпсонов коментар приликом излагања сижеа: „The prince of course disobeys, and in the ninth chamber he finds Baš Celik, in steel chains up to his knees, both arms manacled to the elbows, unable to move an inch" (Thompson 2013: 110; подвлачење М. Ђ.), који би могао да се упоредо чита у контексту сродног приповедачког коментара из Андрићеве приповетке „Пут Алије Ђерзелеза”: „Ђерзелез је плануо. Он је скакао од саме помисли да 
се ти њежни зглобови крше у његовим прстима. Бол му је задавала та њежност и љепота у његовој близини. Ђерзелез се занио и, наравно, постао смијешан" (Андрић 2008: 15; подвлачење М. Ђ.) или пак у односу на наслов сегмента из романа Име руже Умберта Ека - „Naravno, rukopis” (Eko 2014: 9; подвлачење М. Ђ.), где се управо овим типом коментара од стране приповедачке, приређивачке или пак преводилачке инстанце актуализују важне метапоетичке смернице читања дела и контекстуализују потенцијална тумачења која су од непроцењивог значаја за наставу компаративне књижевности на универзитетском нивоу.

Уколико се захваљујући преводилачким напоменама уз имена из неких дела српске књижевности отвара читава вертикала у којој се, нпр. при тумачењу романа На Дрини ћуприја паралелно чита песма „Зидање Скадра”, у интерпретацији поезије Момчила Настасијевића консултује Српски рјечник, а уз неке Кишове текстове на диференциране начине интерпретира његово разумевање фолклорне традиције, онда је евидентно да се таквим поступањима богати процес предавања и проучавања српске књижевности на универзитетском нивоу и у земљи, и у иностранству, а нарочито доприноси њеној широј читалачкој рецепцији.

\section{ЦИТИРАНА ЛИТЕРАТУРА}

Андрић 1965: Иво Андрић, На Дрини ћуприја, Сабрана дела, књига прва,Београд: Просвета, Загреб: Младост, Сарајево: Свјетлост, Љубљана: Државна заложба Словеније.

Андрић 2008: Иво Андрић, „Пут Алије Ђерзелеза”, Сабране приповетке, приређивање и поговор Жанета Ђукић-Перишић, Београд: Завод за уџбенике, стр. $15-22$.

Вук, Рјечник I: Вук Стефановић Караџић, Српски рјечник (1818), Сабрана дела, књига друга, приредио Павле Ивић, Београд: Просвета, 1966.

Вук, Рјечник II: Вук Стефановић Караџић, Српски рјечник (1852), Сабрана дела, књига 11/1, приредио Јован Кашић, Београд: Просвета, 1986.

Вук, СНП, Додатак: Вук Стефановић Караџић, Српске народне приповијетке, Сабрана дела, књига трећа, приредио Мирослав Пантић, Београд: Просвета, 1988.

Вук, СНП II: Вук Стефановић Караџић, Српске народне пјесме II, Сабрана дела Вука Карацића, књига пета, приредила Радмила Пешић, Београд: Просвета, 1988. 
Делић 2008: Јован Делић, „Бурићев Општи семинар: Забиљешке о настави опште књижевности под руководством Војислава Ђурића", Зборник Матице српске за књижевност и језик, књ. 56, св. 2, стр. 451-457.

Десница 2008: Владан Десница, Прољећа Ивана Галеба, Игре прољећа и смрти, Београд: Књига-комерц.

Ђурић 2009: Жељко Ђурић, „Владан Десница и Ерос Секви - преписка и око ње", Зборник Матице српске за књижевност и језик, књ. 57, св. 2, стр. 399-423.

Ђурић 2013: Мина Ђурић, „Нова тумачења традиције и модерности у Срба", у: Jezik, književnost, vrednosti, Književna istraživanja, zbornik radova, uredile Vesna Lopičić, Biljana Mišić Ilić, Niš: Filozofski fakultet, стр. 115-125.

Ђурић 2018: Мина Ђурић, „Српска наука о књижевности у преводу? (Поводом одабраних текстова проф. др Слободана Ж. Марковића објављених у преводима)", у: Слободан Ж. Марковић - човек институција, међународни научни зборник радова, уредили Александар Јерков, Бошко Сувајџић, Београд: Савез славистичких друштава Србије, Филолошки факултет Универзитета у Београду, стр. 85-98.

Караджич 1963: Вук Стефанович Караджич, „Хасанагиница”, у: Эпос сербского народа, Издание подготовил И. Н. Голенищев-Кутузов, перевод А. Ахматовой, Москва: Издательство Академии наук СССР, стр. 180-183, 338-339.

Настасијевић 1991: Момчило Настасијевић, Поезија, Сабрана дела Момчила Настасијевића, књига прва, приредио Новица Петковић, Горњи Милановац: Дечје новине, Београд: Српска књижевна задруга.

Петковић 1991: Новица Петковић, „Критичке напомене”, у: Момчило Настасијевић, Поезија, Сабрана дела Момчила Настасијевића, књига прва, приредио Новица Петковић, Горњи Милановац: Дечје новине, Београд: Српска књижевна задруга, стр. 595-695.

Петковић 1995: Новица Петковић, Настасијевићева песма у настајању, Београд: Београдски издавачко-графички завод.

РСАНУ: Речник српскохрватског књижевног и народног језика, 1-20, Београд: Српска академија наука и уметности, 1959-.

Селимовић 2008: Меша Селимовић, Дервиш и смрт, Београд: Штампар Макарије.

Станковић1899: Борисав Станковић, Из старог јеванђеља, Београд: Радикална штампарија.

Сувајџић 2011: Бошко Сувајџић, „Гојковичин смех: поетика жанра у усменој књижевности", Књижевност и језик, год. 58, бр. 1/2, стр. 61-73.

$$
\text { *** }
$$

Andrić 2016: Ivo Andrić, The Bridge on the Drina, translated by Lovett F. Edwards, Beograd: Dereta.

Andrić 2018: Ivo Andrić, Die Brücke über die Drina, Deutsch von Ernst E. Jonas, über arbeitet von Katharina Wolf-Grießhaber, Beograd: Dereta. 
Benedikt1976: Rut Benedikt, Obrasci kulture, preveo Božidar Marković, Beograd: Prosveta.

Desnica 1960: Vladan Desnica, Niespokojne wiosny, przełożył Zygmunt Stoberski, Warszawa: Ministerstwo oborony narodowej.

Desnica 1962: Vladan Desnica, A tavasz és a halál játékai, fordította Csuka Zoltán, Novi Sad: Forum.

Desnica 1967: Vladan Desnica, Vlnenie jarí a umierania, preložil Jozef Em. Cubínek, doslov napísal Ján Frýdecký, vysvetlivky spracoval Jozef Šimončič, Bratislava: Tatran.

Edwards 2016: Lovett F. Edwards, „Note”, y: Ivo Andrić, The Bridge on the Dri$n a$, translated by Lovett F. Edwards, Beograd: Dereta, стр. 19-20.

Eko 2014: Umberto Eko, Ime ruže, prevela Milana Piletić, Beograd: Vulkan izdavaštvo.

Đurišin 1992: Dioniz Đurišin, „Književni prevod kao posrednik među književnostima”, prevela Jelica Alaburić, Prevodilac, god.11, br. 1/4, str. 31-39.

Hodel 2014: Robert Hodel, „O književnom prevođenju (Momčilo Nastasijević: Sind Flügel wohl...)", prevela Olga Stojanović Fréchette, Raskršća književnog juga (Od Dositeja do Mihailovića), Beograd: Filološki fakultet, Institut za književnost i umetnost, Čigoja štampa, str. 65-85.

Jonas, Wolf-Grießhaber 2018: Ernst E. Jonas, Katharina Wolf-Grießhaber, „Glossar”, y: IvoAndrić, Die Brücke über die Drina, Deutsch von Ernst E. Jonas, über arbeitet von KatharinaWolf-Grießhaber, Beograd: Dereta, стр. 482-484.

Karadžić 1825: Vuk Stefanović Karadžić, Volkslieder der Serben, 1, metrisch übersetzt und historisch eingeleitet von Talvj, Halle: Rengerschen Buchhandlung.

Karadžić 1827: Vuk Stefanović Karadžić, Serbian Popular Poetry, translated by John Bowring, London: John Bowring.

Karadžić 1834: Vuk Stefanović Karadžić, Chants populaires des Serviens, recueillis par Wuk Stéphanowitsch, et traduits, d'après Talvy, par Mme Élise Voïart, Tome I, Paris: J. Albert Mercklein.

Karadžić 1853: Vuk Stefanović Karadžić, Volkslieder der Serben, metrisch übersetzt und historisch eingeleitet von Talvj, neue umgearbeitete und vermehrte Auflage, ersterTheil, Leipzig: F. A. Brockhaus.

Karadžić 2015: Vuk Stefanović Karadžić, „Đurđevdan”, y: Vuk Stefanović Karadžić, 1787-1864-2014,Mündliches Volksgut der Serben, zweite Ausgabe, Herausgabe, Vorwort und Anmerkungen Boško Suvajdžić, Übersetzung Annette Đurović, Belgrad: Vukova zadužbina, Čigoja štampa.

Kiš 2007: Danilo Kiš, „Nojev kovčeg (Iz beležnice g. Maka)”, Varia, Sabrana dela Danila Kiša, knjiga dvanaesta, priredila Mirjana Miočinović, Beograd: Prosveta, стр. 44-47.

Lobato, Brisolara 2015: Carolina Rodrigues Lobato, Valéria Silveira Brisolara, „The Importance of Being a Translator: Analyzing One of Oscar Wilde's Most Iconic Plays", Translatio, Porto Alegre, n. 9, Junho de 2015, стр. 29-37.

Nastasijević2013: Momčilo Nastasijević, Sind Flügel wohl..., Gedichte und Prosa, heraus gegeben und übertragen von Robert Hodel, Leipzig: Leipziger Literaturverlag. 
Nemark 1988: Peter Nemark, A Textbook of Translation, Prentice Hall: Hertfordshire.

Thompson 2013: Mark Thompson, Birth Certificate: The Story of Danilo Kiš, Ithaca, NY, London: Cornell University Press.

Wilde 2011: Oscar Wilde, „The Importance of Being Earnest”, The Plays of Oscar Wilde, London: Collins Classics, cтр. 247-340.Wilde 2014: Oscar Wilde, A Importância de ser prudente, Tradução de Petrucia Finkler, Porto Alegre: L\&PM.

\section{TRANSLATORS' NOTES ON WORKS OF SERBIAN LITERATUREIN UNIVERSITY TEACHING PROCESS}

This paper analyzes the role and the importance of translators' notes on works of Serbian literature as a kind of mediator among different languages and cultures. Additional notes given by translators of literary works are interpreted as important motivation factors inencouraging deeper reception of Serbian literature in another academic community, reaching also a wider audience.

Keywords: Serbian literature, Serbian literature of the $20^{\text {th }}$ century, translation, translators' notes, university teaching process. 